


\section{DOMESTIC PREFERENCE}

GUIDANCE NOTE ON PROCUREMENT

JUNE 2018 


\section{(c) $(9)$ Creative Commons Attribution-NonCommercial-NoDerivs 3.0 BY NC ND IGO license (CC BY-NC-ND 3.0 IGO)}

(C) 2018 Asian Development Bank

6 ADB Avenue, Mandaluyong City, 1550 Metro Manila, Philippines

Tel +632632 4444; Fax +6326362444

www.adb.org

Some rights reserved. Published in 2018.

ISBN 978-92-9261-184-2 (print), 978-92-9261-185-9 (electronic)

Publication Stock No. TIM189233-2

DOI: http://dx.doi.org/10.22617/TIM189233-2

The views expressed in this publication are those of the authors and do not necessarily reflect the views and policies of the Asian Development Bank (ADB) or its Board of Governors or the governments they represent.

ADB does not guarantee the accuracy of the data included in this publication and accepts no responsibility for any consequence of their use. The mention of specific companies or products of manufacturers does not imply that they are endorsed or recommended by ADB in preference to others of a similar nature that are not mentioned.

By making any designation of or reference to a particular territory or geographic area, or by using the term "country" in this document, $\mathrm{ADB}$ does not intend to make any judgments as to the legal or other status of any territory or area.

This work is available under the Creative Commons Attribution-NonCommercial-NoDerivs 3.0 IGO license (CC BY-NC-ND 3.0 IGO) http://creativecommons.org/licenses/by-nc-nd/3.o/igo/. By using the content of this publication, you agree to be bound by the terms of this license. For attribution and permissions, please read the provisions and terms of use at https://www.adb.org/terms-use\#openaccess.

This CC license does not apply to non-ADB copyright materials in this publication. If the material is attributed to another source, please contact the copyright owner or publisher of that source for permission to reproduce it. ADB cannot be held liable for any claims that arise as a result of your use of the material.

Please contact pubsmarketing@adb.org if you have questions or comments with respect to content, or if you wish to obtain copyright permission for your intended use that does not fall within these terms, or for permission to use the ADB logo.

Notes:

In this publication, “\$” refers to United States dollars.

Corrigenda to ADB publications may be found at http://www.adb.org/publications/corrigenda. 
Figures and Box

About This Publication

v

Abbreviations

viii

Executive Summary

ix

$\begin{array}{ll}\text { I. Introduction } & 1\end{array}$

II. Summary of the Domestic Preference Application Process 4

III. ADB's Practiced Approach to Domestic Preference 5

Appendix 1: Using Domestic Preference-Rationale and Challenges $\quad 7$

Appendix 2: Domestic Preference by Application of Price Margin 


\section{FIGURES}

1. Domestic Preference in the ADB Procurement Cycle 2

2. Domestic Preference Application Process 4

BOX

The Impact of Domestic Preference on a Project Should Be Understood 


\section{ABOUT THIS PUBLICATION}

In April 2017, the Asian Development Bank (ADB) approved its new procurement framework, the ADB Procurement Policy: Goods, Works, Nonconsulting and Consulting Services (2017, as amended from time to time); and the Procurement Regulations for ADB Borrowers: Goods, Works, Nonconsulting and Consulting Services (2017, as amended from time to time). These replace the former Guidelines on the Use of Consultants (2013, as amended from time to time) and Procurement Guidelines (2015, as amended from time to time). The procurement policy and the procurement regulations address the procurement activities of project executing agencies and implementing agencies on projects financed in whole or in part by a loan or grant from ADB, or by ADB-administered funds. ADB designed the 2017 procurement policy to deliver significant benefits and flexibility throughout the project procurement cycle, as well as to improve project delivery through a renewed focus on the concepts of quality, value for money (VFM), and fitness for purpose.

This note is part of a series of guidance notes published by ADB in 2018 to accompany the 2017 procurement policy and the procurement regulations. Each note discusses a topical issue for borrowers (including grant recipients), bidders, and civil society under the new framework (see list below). The guidance notes cross-reference each other frequently and should be read in conjunction. All references to "guidance notes" pertain to these notes. The notes may be updated, replaced, or withdrawn from time to time.

\section{List of Guidance Notes for the 2017 ADB Procurement Policy and the Procurement Regulations}

1. Value for Money

2. Procurement Risk Framework

3. Strategic Procurement Planning

4. Procurement Review

5. Alternative Procurement Arrangements

6. Open Competitive Bidding

7. Price Adjustment

8. Abnormally Low Bids

9. Domestic Preference

10. Prequalification

11. Subcontracting

12. Consulting Services Administered by ADB Borrowers

13. Nonconsulting Services Administered by ADB Borrowers
14. High-Level Technology

15. Quality

16. Bidding-Related Complaints

17. Noncompliance in Procurement

18. Standstill Period

19. State-Owned Enterprises

20. E-Procurement

21. Framework Agreements for Consulting Services

22. Public-Private Partnerships

23. Contract Management

24. Fragile, Conflict-Affected, and Emergency Situations 
ADB procurement reforms intend to ensure VFM by improving flexibility, quality, and efficiency throughout the procurement cycle (see illustration below and the Guidance Note on Value for Money). VFM is part of a holistic procurement structure with three support pillars: efficiency, quality, and flexibility. The two key principles of transparency and fairness weave across all elements of the structure.

\section{Transparency}

\section{Value for Money}

The effective, efficient, and economic use of resources, which requires an evaluation of relevant costs and benefits along with an assessment of risks, nonprice attributes, and/or total cost of ownership as appropriate

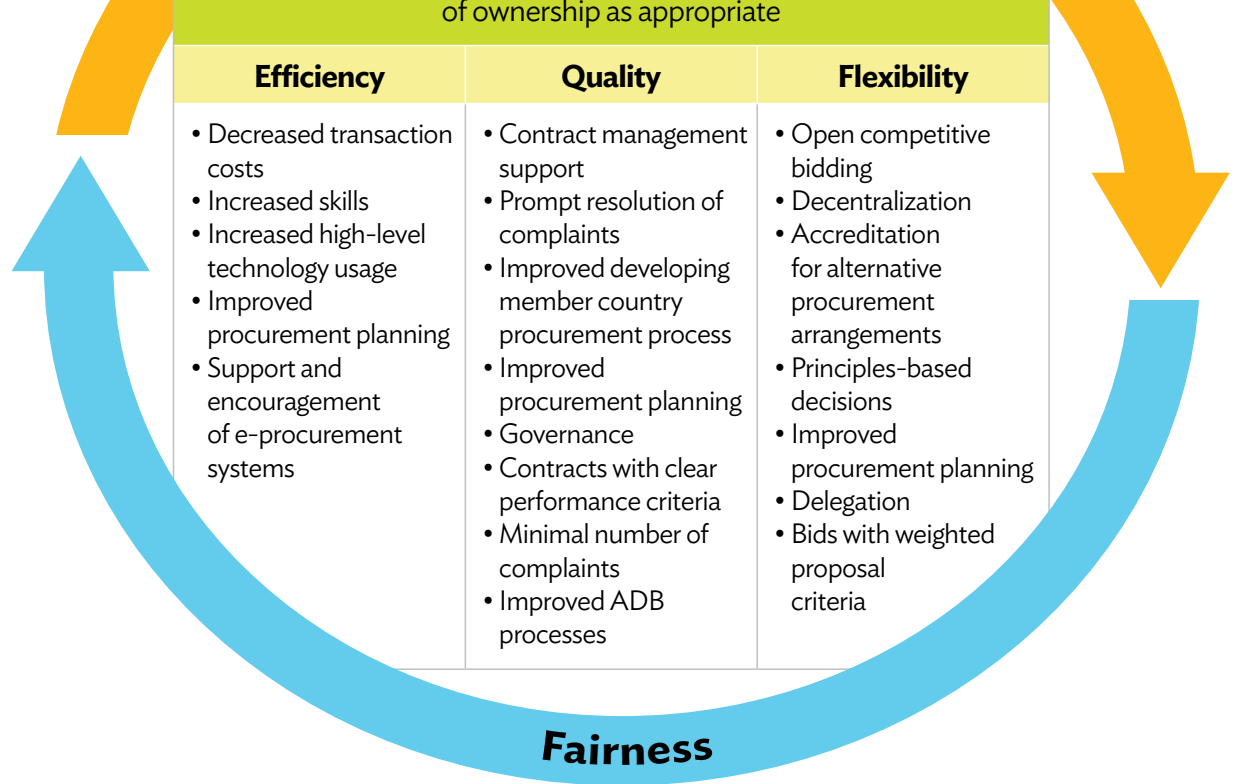

\section{(1) Time}

Time is an important element of VFM. When a project is delivered promptly or when a process is completed rapidly, greater value is created for all stakeholders. For example, a road project completed early provides economic benefit, security, or other value to the community it serves. It increases the return on investment to the executing agency and accelerates the project and payment cycle to the successful bidder. Likewise, a project delivered late loses significant value.

When considering VFM in the context of procurement, pay attention to anything that (i) shortens the procurement cycle time frame, or (ii) accelerates delivery of the development project. 


\section{$\Omega$ Objective}

This guidance note is intended to assist readers by elaborating on and explaining ADB's 2017 procurement policy and procurement regulations for borrowers (including grant recipients).

This note identifies additional information for the reader to consider when applying ADB's procurement policy and procurement regulations to their circumstances.

\section{Living Document}

This guidance note is intended to be a living document and will be revised as required.

Be sure to check the ADB Business Center website for the latest version and updates, https://www.adb.org/business/main.

\section{? The Reader}

In many circumstances, readers are expected to use this guidance note in a manner unique to their needs. For consistency throughout the suite of guidance notes, the following assumption is made about the reader:

The reader is a professional involved in activities financed in whole or in part by an ADB loan or grant, or by ADB-administered funds.

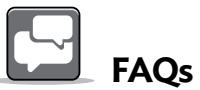

Frequently asked questions, clarifications, examples, additional information, links to training, and other useful resources will be made available on the ADB website.

Be sure to check the ADB Business Center website for more information, https://www.adb.org/business/main.

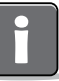

\section{Legal and Order of Priority}

This guidance note explains and elaborates on the provisions of the Procurement Regulations for ADB Borrowers: Goods, Works, Nonconsulting and Consulting Services (2017, as amended from time to time) applicable to executing (and implementing) agencies under sovereign (including subsovereign) projects financed in whole or in part by an investment loan from ADB (i.e., excluding ADB results- or policy-based loans), ADB-financed grant (excluding ADB-administered technical assistance and staff consultancies), or by ADB-administered funds.

In the event of any discrepancy between this guidance note and the procurement regulations, the latter will prevail. The financing agreement governs the legal relationships between the borrower and ADB. The rights and obligations between the borrower and the provider of goods, works, or services are governed by the specific procurement document issued by the borrower and by the contract signed between the borrower and the provider, and not by this guidance note. 


\begin{tabular}{|c|c|c|}
\hline ADB & - & Asian Development Bank \\
\hline $\mathrm{CIF}$ & - & cost, insurance, and freight \\
\hline CIP & - & $\begin{array}{l}\text { carriage and insurance paid to } \\
\text { (named place of destination) }\end{array}$ \\
\hline EXW & - & $\begin{array}{l}\text { ex works, ex factory, ex warehouse, } \\
\text { or off-the-shelf }\end{array}$ \\
\hline GNI & - & gross national income \\
\hline OCB & - & open competitive bidding \\
\hline SMEs & - & small and medium-sized enterprises \\
\hline VFM & - & value for money \\
\hline
\end{tabular}




\section{EXECUTIVE SUMMARY}

This guidance note brings together ADB practiced approaches to domestic preference in the procurement of goods, works, and consulting services to be implemented for projects financed in whole or in part by an ADB loan or grant, or by ADB-administered funds under its 2017 procurement policy.

Previously, domestic preference was allowed only when international competitive bidding was used. Through the introduction of open competitive bidding, the procurement policy has removed the distinction between "international" and "national" competitive bidding. Therefore, domestic preference may now be applied even when national advertising is used.

The domestic preference schemes allowed in this guidance note for the procurement of goods and works are very similar to what were applied in the past under the ADB Procurement Guidelines (2015, as amended from time to time). However, more flexibility is allowed. The margins of preference are no longer fixed and may be adjusted within specified ceilings.

For consulting services, this guidance note introduces a new method for domestic preference. This method allows borrowers (including grant recipients) to include the "use of national experts for key positions" as an evaluation criterion in technical evaluation. In the past, the only possibility available was to require certain positions to be "national." 


\section{Introduction}

1.1 The purpose of this guidance note is to clarify and elaborate on ways where domestic preference may be applied in projects financed in whole or in part by a loan or grant from the Asian Development Bank (ADB), or by ADB-administered funds. Under its Procurement Regulations for ADB Borrowers: Goods, Works, Nonconsulting and Consulting Services (2017, as amended from time to time), ADB may accept the application of provisions that promote or encourage the development of domestic industry through domestic preference schemes if $A D B$ is satisfied that such provisions meet its core procurement principles. ${ }^{1}$

1.2 The ADB Procurement Policy: Goods, Works, Nonconsulting and Consulting Services (2017, as amended from time to time) encourages the development of domestic contracting, consulting, and manufacturing industries in the country of the borrower. ADB supports this development in two ways:

(i) Through its operations: loans and grants financed in whole or in part by $A D B$, or by $A D B$-administered funds, will periodically focus on the development of specific sectors, industries, or, in its private sector operations, a specific entity through equity investments, guarantees, and/or loans. ADB may also make available trade finance to facilitate both trade and development of domestic firms.

(ii) Through domestic preference schemes: ADB may allow borrowers (including grant recipients) to apply preferences to qualified domestic firms and individuals, and domestically produced goods.

This guidance note has been prepared to give information on this second approach. Figure 1 shows where domestic preference features in the ADB procurement cycle.

1.3 While the 2017 procurement regulations give flexibility in applying domestic preference, borrowers need to be aware of the arguments for and against the use of such a preference, its costs and benefits, and what alternatives may exist to promote local participation in public procurement. Appendix 1 discusses the rationale and challenges of using domestic preference.

When development partners allow domestic preference margins in ADB's developing member countries, ADB may allow the application of such margins under ADB projects. Any approach to applying a domestic preference scheme (and any applicable price margin) must be reflected in the project procurement plan. See the procurement regulations (in Appendix 3, paras. 80-82). 
Figure 1: Domestic Preference in the ADB Procurement Cycle

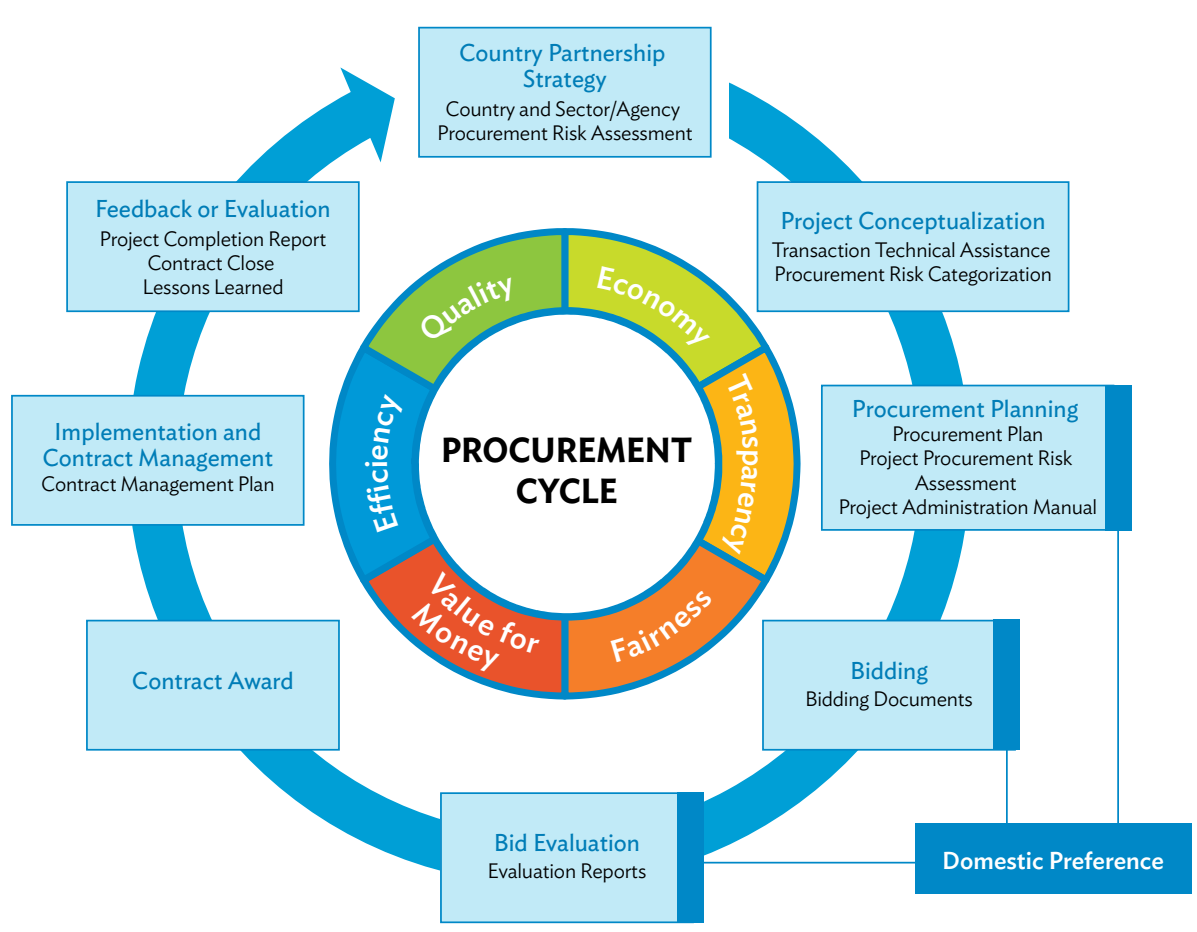

Source: Asian Development Bank.

1.4 ADB applies domestic preference under projects that it finances with caution and only when such a preference scheme can be transparently and precisely applied within the tolerances described here (see Box). This is due to the inherent conflict of domestic preference schemes with ADB's core procurement principles of economy and fairness, combined with the absence of evidence and impact evaluation on these schemes.

1.5 Domestic preference may be applied to the procurement of

(i) goods,

(ii) works, and

(iii) consulting services. 


\section{Box}

\section{The Impact of Domestic Preference on a Project Should Be Understood}

When considering applying domestic preference, it is vital that a thorough market assessment has been undertaken to ensure that giving preference to domestic contractors or locally made goods does not hurt competition. It is equally important to ensure that local suppliers and locally made goods adhere to the required technical, environmental, and labor standards.

Wider social and economic impact should also be considered in providing domestic preference. For example, allowing domestic preference may support the development of the private sector in the borrower's country by giving them preferences, hence a higher chance, to win procurement contracts. However, a poorly designed domestic preference scheme may result in lower quality of goods, works, or services provided by the eligible supplier or contractor. Alternately, when price preference is applied, the borrower will have to pay more for the same or similar goods or services.

It can also be argued that the application of domestic preference schemes, over the long term, can reduce competition and remove competitive pressure on domestic industry to match the efficiencies of global best-in-class suppliers or contractors. The consumer bears these higher costs. 


\section{Summary of the Domestic Preference Application Process}

2.1 Figure 2 summarizes the domestic preference application process in projects financed in whole or in part by an ADB loan or grant, or by ADB-administered funds for goods, works, and consulting services.

Figure 2: Domestic Preference Application Process

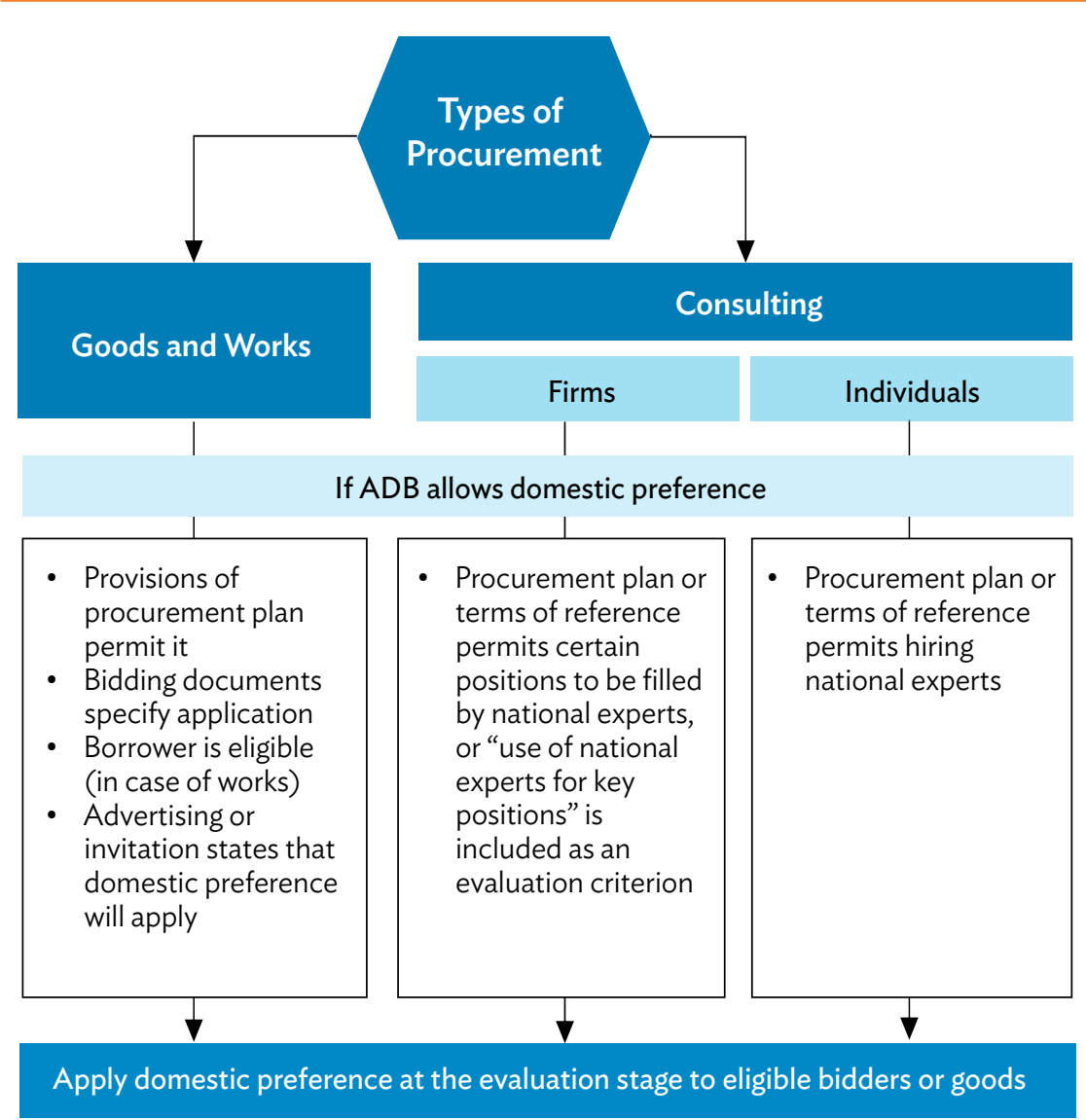

Source: Asian Development Bank. 


\section{ADB's Practiced Approach to Domestic Preference}

3.1 For operations financed in whole or in part by an ADB loan or grant, or by ADB-administered funds, to which the 2017 procurement regulations apply, domestic preference may be implemented using appropriate contract packaging strategies, procurement methods, or qualification criteria that support greater domestic participation. These may be used if they do not adversely affect project implementation or significantly increase project risks. A more regulated approach to domestic preference is to grant preferences at the evaluation stage, which will be discussed for each type of procurement.

\section{A. Goods and Works}

3.2 A margin of preference may be granted for domestically manufactured goods and domestic contractors when provided for in the procurement plan. However, even if eligible to apply domestic preference, borrowers may choose not to apply the preference in any specific procurement transaction as agreed in the procurement plan, e.g., when the domestic market is competitive or when domestic participation is unlikely.

\subsection{When allowed by ADB, the margin is applied during bid evaluation.} The scheme grants a margin of preference for domestically manufactured goods to be procured and domestic contractors to be engaged under projects financed in whole or in part by an ADB loan or grant, or by ADB-administered funds. Applying the scheme is subject to certain eligibility requirements for the goods to be procured in supply contracts and for domestic contractors in works contracts. For works contracts, the country is eligible only if its per capita gross national income (GNI) falls below a predetermined level. ${ }^{2}$

3.4 For ADB, domestic preference for goods, works, and single responsibility, supply and installation, or turnkey contracts will only apply if

(i) express provisions allow the use of such preference in the relevant project procurement plan for situations involving open competitive bidding (OCB);

(ii) the applicable bidding documents specify in detail how the preference will be applied;

2 This is defined annually by ADB and agreed on with the borrower on a case-by-case basis. To foster harmonization, ADB may rely on the GNI thresholds defined annually by the World Bank for application of domestic preference. 
(iii) the borrower continues to remain eligible for the preference at the time of advertising (e.g., GNI per capita is under the applicable limit in the context of works contracts); and

(iv) the applicable advertisement or invitation, whether for prequalification or for bidding, clearly states that the domestic preference scheme will apply.

3.5 Appendix 2 describes provisions included in ADB's standard bidding documents for applying domestic preference during bid evaluation for goods, works, and single responsibility, supply and installation, or turnkey contracts.

\section{B. Consulting Services}

\section{Consulting Firms}

3.6 For selection methods using OCB (quality- and cost-based selection, quality-based selection, fixed budget selection, consultants' qualifications selection, and least-cost selection), ${ }^{3}$ if there is adequate local capacity, reflecting project needs and requirements, $\mathrm{ADB}$ may agree to allow the borrower to require certain positions to be "national" in the terms of reference. This approach requires consulting firms to propose only national experts for such positions. Non-national experts will not be evaluated and a score of zero given.

3.7 Another approach that ADB may agree to allow is to include the "use of national experts for key positions" as an evaluation criterion, which should be allocated up to $10 \%$ of scoring weight. The proposal of the short-listed firm with the most national inputs of key experts (i.e., the number of person months) that meet the qualification requirements will be given the maximum score possible for this criterion. The scores of the other proposals will be set in proportion to this maximum score depending on the level of national inputs of each proposal.

\section{Individual Experts}

3.8 In selecting individual experts, the terms of reference may specify the requirement of national consultants for an assignment, if there is adequate justification for this approach. Relevant considerations may include specific country and experience requirements, in addition to budgetary constraints, or the need for sustained engagement of an ADB developing member country that would be more easily undertaken by a national consultant.

3 See the procurement regulations (in Appendix 4, paras. 5-10). 


\section{Appendix 1: Using Domestic}

\section{Preference-Rationale and Challenges}

\section{A. Rationale}

A1.1 The main argument supporting the use of domestic preference is that businesses in lower-income countries are at a disadvantage when competing with foreign firms, given that there may be an asymmetry of information between local and foreign firms. Foreign firms may have better access to technology, finance, and infrastructure to increase productivity and lower production costs. Among other things, foreign firms may benefit from economies of scale. Thus, local firms in lower-income countries may need preference to be able to compete with foreign firms in terms of price and/or other protective measures.

A1.2 Awarding contracts to local firms is deemed to give greater social and economic benefit to local communities, in the form of increased employment, incomes, and tax revenues, compared to contracts awarded to foreign firms that produce, employ staff, and pay taxes offshore. By granting domestic preference, it is assumed that local benefits incurred by awarding a contract to a local firm outweigh the potential for higher financial costs to the executing agency compared to a situation where the contract was awarded to a foreign firm.

\section{B. Challenges}

A1.3 The main challenges associated with using domestic preference include

(i) Lack of Data and Analysis. Few procurement agencies track details of the use of domestic preferences, and few assess or evaluate their impact. Without such data, it will be difficult to make evidence-based policy decisions. Available evaluations - mainly on domestic programs to support disadvantaged groups, such as indigenous groups, small and medium-sized enterprises (SMEs), ${ }^{1}$ or female-led businessesare mixed but tend to show that preferences are not likely costeffective and have minimal impact on promoting sustainability.

(ii) Misalignment of Incentives. Borrowers (including grant recipients) sometimes lack information on the use of domestic preferences, or executing agencies do not see the benefit of paying more for

For a detailed review of government approaches to SME preferences in public procurement, see ADB. 2012. SME Development: Government Procurement and Inclusive Growth. Manila. 
something that they could procure at a lower price. The level of price preference set down in the past by most multilateral development banks could be a deterrent-for example, 15\% (fixed) for goods-and could be material for the agency's budget.

(iii) Administrative Costs. Bidders and executing agencies may both be put off by the information required to calculate the local content and/or otherwise determine eligibility. Domestic bidders may not want to disclose details of their operating or production costs. Moreover, to ensure that criteria are met, executing agencies would need additional monitoring of actual costs and impacts. These issues may be further complicated in a world of integrated supply chains that make determination of local content difficult. This could be a disincentive for firms that have adopted integrated supply chains to meet such preference requirements.

(iv) Other Problems. Other difficult questions when considering the use of domestic preference include: (a) how to determine the optimal level of price preference, the appropriate level of local content, and the correct way to calculate that content; (b) which firms should benefit from domestic preference; and (c) which countries should be eligible for domestic preference, and based on what metric (gross national income per capita or others).

A1.4 As a result, experience from multilateral development banks indicates that few borrowers tend to request domestic preference, and if used, it may have very little impact on contract award decisions. ${ }^{2}$

2 M. Alexander and C. Fletcher. 2012. The Use and Impact of the Bank's Policy of Domestic Preferences. World Bank Discussion Paper. Washington, DC. 


\section{Appendix 2: Domestic Preference by Application of Price Margin}

A2.1 The provisions on domestic preference are included in the Asian Development Bank's (ADB's) standard bidding documents for transactions where the Procurement Regulations for ADB Borrowers: Goods, Works, Nonconsulting and Consulting Services (2017, as amended from time to time) apply. In case of any discrepancy between the provisions in this guidance note and any specific procurement document issued by an executing agency, the provisions of the procurement document shall prevail.

\section{A. Preference for Domestically Manufactured Goods}

A2.2 The borrower (or grant recipient) may, with the agreement of ADB, grant a margin of preference in the evaluation of bids under open competitive bidding (OCB) procedures (whether internationally or nationally advertised) to bids offering certain goods manufactured in the country of the borrower, when compared to bids offering such goods manufactured elsewhere.

A2.3 In such cases, bidding documents shall clearly indicate any preference to be granted to domestic manufactured goods and the information required to establish the eligibility of a bid for such preference. The nationality of the manufacturer or supplier is not a condition for such eligibility. The methods and stages set forth hereunder shall be followed in the evaluation and comparison of bids.

\section{B. For Supply Contracts}

A2.4 Substantially responsive bids shall be classified in one of the following three groups for comparison:

(i) Group A. Bids exclusively offering goods manufactured in the country of the borrower, if the bidder establishes to the satisfaction of the borrower and $A D B$ that: 
(a) labor, raw material, and any component from within the country of the borrower will account for normally $30 \%$ or more of the EXW' price of the product offered; ${ }^{2}$ and

(b) the production facility in which those goods will be manufactured or assembled has been engaged in manufacturing and/or assembling such goods at least since the time of bid submission.

(ii) Group B. All other bids offering goods manufactured in the country of the borrower.

(iii) Group C. Bids offering goods manufactured abroad that have been already imported or that will be directly imported.

A2.5 The price quoted for goods in bids of groups $A$ and $B$ shall include all duties and taxes paid or payable on the basic materials or component purchased in the domestic market or imported, but shall exclude sales and similar taxes on the finished product. The price quoted for goods in bids of group $\mathrm{C}$ shall be on $\mathrm{CIF}$ (port of destination) or CIP (place of destination), which is exclusive of customs duties and other import taxes already paid or to be paid. ${ }^{3}$

A2.6 In the first step, all evaluated bids in each group shall be compared to determine the lowest bid in each group. Such lowest evaluated bids shall be compared with each other and if, as a result of this comparison, a bid from group $A$ or group $B$ is the lowest, it shall be selected for the award.

A2.7 If, as a result of the comparison under the previous paragraph, the lowest evaluated bid is a bid from group $C$, the lowest evaluated bid from group $C$ shall be further compared with the lowest evaluated bid from group $A$, after adding to the evaluated price of goods offered in the bid from group C, for the purpose of this further comparison only, an amount equal to normally not more than $15 \%$ of the CIF or CIP bid price. ${ }^{4}$ The lowest evaluated bid determined from this last comparison shall be selected.

1 EXW refers to ex works, ex factory, ex warehouse, or off-the-shelf, as applicable. For further definitions, refer to Incoterms 2010 published by the International Chamber of Commerce, Paris. https://iccwbo.org/resources-for-business/incoterms-rules/incoterms-rules-2010/

2 Domestic preference cannot be applied to goods offered in a schedule if one item has more than $30 \%$ domestic value-added but the total domestic value-added does not result in the required minimum percentage (normally $30 \%$ ) of the total price of the schedule. Domestic value-added generally comprises domestic labor, the domestic content of materials, domestic overheads, and profits from the stage of mining the raw material until final assembly. If calculating domestic value-added is difficult and time consuming, a "direct import content" approach may be used as proxy. Under this approach, if the direct import content under the cost, insurance, and freight (CIF) or carriage and insurance paid to (CIP) Incoterms are less than $50 \%$ of the quoted EXW price, the goods are eligible for the preference.

3 CIF refers to cost, insurance, and freight, and CIP refers to carriage and insurance paid to. For further definitions, refer to Incoterms 2010 (footnote 1).

4 The applicable percentage is specified in the relevant procurement plan and bidding document. The borrower needs to provide justifications for the selected margin of preference. 


\section{For Single Responsibility, Supply and Installation, or Turnkey Contracts}

A2.8 In the case of single responsibility, supply, and installation, or turnkey contracts in which a number of discrete items of equipment is grouped into one contract package or in a bid package involving multiple items, the preference margin shall not be applied to the whole package, but only to the locally manufactured equipment within the package. ${ }^{5}$ However, the provisions below apply only, as noted, if customs duties are excluded from bid prices, and the price of imported goods is quoted on a CIF or CIP basis.

(i) Equipment offered from abroad shall be quoted CIF or CIP, and equipment offered locally EXW (free of sales and similar taxes).

(ii) All other components, such as design, works, installation, and supervision, shall be quoted separately.

A2.9 The procedure is as follows:

(i) Bids should not be classified into groups $A, B$, or C.

(ii) In the comparison of bids, only the CIF or CIP price in each bid of the equipment offered from outside the borrower's country shall be increased by the specified preference percentage (normally not more than $15 \%)^{6}$

(iii) No preference shall be applied for any associated services or works included in the package.

\section{Preference for Domestic Contractors}

A2.10 For contracts for works to be awarded based on OCB, preference for domestic contractors ${ }^{7}$ is applicable only in countries that qualify. ${ }^{8}$ Eligible borrowers may, with the agreement of $A D B$, grant a margin of preference of normally not more than $7.5 \%$ to domestic contractors ${ }^{9}$ in accordance with, and subject to, the following provisions:

5 A margin of preference may be applied to domestically manufactured goods in single responsibility turnkey (including design-build) contracts, and in large and complex contracts (for goods and related discrete items of goods and supplies grouped in one contract package) when the cost of goods and supplies for permanent works is estimated prior to bidding to be equal to or to exceed $60 \%$ of such works.

6 The applicable percentage is specified in the relevant procurement plan and bidding document. The borrower needs to provide justifications for the selected margin of preference.

7 Domestic contractors may be eligible for preference for works contracts that may include construction, land clearing and leveling, land development, field drainage, well drilling, site clearing for urban projects, installation of water supply mains, erection of electricity lines, aerial photography, mapping, or crop spraying.

8 As per country qualifying per capita GNI levels applicable for such purpose notified by ADB from time to time. See also footnote 2.

9 The applicable percentage is specified in the relevant procurement plan and bidding document. The borrower needs to provide justifications for the selected margin of preference. 
(i) Contractors applying for such preference shall be asked to provide, as part of the data for qualification, at prequalification and/or at the bidding stage, such information, including details of ownership, as shall be required to determine whether, according to the classification established by the borrower and accepted by ADB, a particular contractor or group of contractors qualifies for a domestic preference. The bidding documents shall clearly indicate the information required from bidders and the method that will be followed in the evaluation and comparison of bids to give effect to such preference..$^{10}$

(ii) After bids have been received and reviewed by the borrower, substantially responsive bids shall be classified into the following groups:

(a) Group A. Bids offered by domestic contractors eligible for the preference.

(b) Group B. Bids offered by other contractors.

A2.11 For evaluation and comparison of bids, an amount equal to the specified preference percentage (i.e., normally not more than $7.5 \%)^{11}$ of the bid amount shall be added to bids received from the contractors in group $B$.

10 To be eligible, contractors must be determined to be genuine domestic contractors. The standard bidding documents include specific agreed upon criteria for eligibility that are included in the specific bidding document to be issued. ADB will not object if the borrower wishes to grant preference to state-owned construction corporations or firms if they are eligible to bid.

1 The applicable percentage is specified in the relevant procurement plan and bidding document. The borrower needs to provide justifications for the selected margin of preference. 


\section{Domestic Preference \\ Guidance Note on Procurement}

This guidance note brings together ADB practiced approaches to domestic preference in the procurement of goods, works, and consulting services to be implemented for projects financed in whole or in part by a loan or grant from ADB, or by ADBadministered funds under its 2017 procurement policy. The new domestic preference scheme allows more flexibility, with margins of preference that are adjustable within specified ceilings. This guidance note introduces a new domestic preference method for consulting services which allows borrowers to include the "use of national experts for key positions" as an evaluation criterion in technical evaluation. Previously, the only possibility available was to require certain positions to be "national."

\section{About the Asian Development Bank}

ADB's vision is an Asia and Pacific region free of poverty. Its mission is to help its developing member countries reduce poverty and improve the quality of life of their people. Despite the region's many successes, it remains home to a large share of the world's poor. $A D B$ is committed to reducing poverty through inclusive economic growth, environmentally sustainable growth, and regional integration.

Based in Manila, ADB is owned by 67 members, including 48 from the region. Its main instruments for helping its developing member countries are policy dialogue, loans, equity investments, guarantees, grants, and technical assistance.

\section{$\mathrm{ADB}$}

